\title{
Post-modern Dönemde Senaristin ve İzleyicinin Rolü: Yapay Zeka, İnteraktif Drama ve Sinemanın Geleceğine Dair Bir Öngörü
}

\author{
Bahar MURATOĞLU-PEHLIVAN ve Süleyman Kıvanç TÜRKGELDİ²
}

$\ddot{O} z$

Bu çalışmanın amacı, interaktif dramalardaki izleyici deneyimini ve gelecekte bu deneyimin yapay zeka tarafindan yazılacak senaryolarla mümkün olup olamayacağını, post-modern dönemde yazarın otoritesinin sarsılması ve okurun / izleyicinin pasif konumundan çıarak aktif bir rol üstlenmesi çerçevesinde tartı̧̧maktır. Bu amaçla; ilk önce postmodern dönem, yazarın ölümü ve okurun doğumu tartışmaları aktarılmış; daha sonra interaktivite kavramı, interaktif drama, izleyicinin rolü ve doğrusal anlatılara kıyasla izleyici deneyimi tartışılmış; ardından da yapay zeka ve yaratıcllık üzerine olan literatüre yer verilmiştir. Söz konusu literatür ve tartışmalar çerçevesinde, yapay zekanın insan yaratıcllğına, bir başka deyişle insan yazımı senaryolara yakın bir üretim gerçekleştirip gerçekleştiremeyeceği ve eğer yapay zeka bunu başarabilirse, izleyicinin katıllımcı konumuna geçerek, yapay zekanın ürettiği senaryolar üzerinden interaktif bir sinema deneyimi yaşayıp yaşayamayacağı tartışması üzerinde durulmuştur. Ayrıca bu deneyimin, yakın gelecekte, izleyicinin / katıllımcının seçimlerine göre anlık senaryolar ve patikalar üretebilen ve bunları anlık olarak görselleştirebilen bir teknoloji sayesinde var olup olamayacağı; eğer böyle bir teknoloji mümkün olursa, ortaya çıkan eserin hala sinema olarak kabul edilip edilemeyeceği ve bu yeni türün post-modern okuma anlayışıyla bağlantısı tartışılmıştır. Çalışmada yöntem olarak literatür taraması kullanılmış ve kuramsal tartışmalara yer verilmiştir.

Anabtar Sözcükler. Post-modernizm, Yapay zeka, İnteraktif drama, Sinema, İzleyici deneyimi

Scriptwriter's and Audience's Role in Post-modern Era: Artificial Intelligence, Interactive Drama and A Prediction for the Future of Cinema

\section{Abstract}

The purpose of this paper is to discuss audience experience in interactive dramas, and whether it will be possible in the future to have this experience via scenarios written by artificial intelligence; within the scope of writer's diminishing authority and reader's/audience's active role in the post-modern era. For this purpose; first, the discussions on post-modern era, death of the author and birth of the reader were cited; afterwards, the concept of interactivity, interactive dramas, role of the audience and audience experience in comparison with linear storytelling were discussed; then by, literature on artificial intelligence, and creativity was mentioned. Within the scope of these literature and discussions, it was questioned that whether artificial intelligence could reach human creativity, and if this is possible, whether audience can have an interactive cinema experience via scenarios produced by artificial intelligence. Besides, it was discussed that whether it would be possible to have this experience in near future by means of a technology, which could write instant scenarios and pathways, and instantly visualize them; if it is possible, can the outcome still be considered as cinema and what is the relationship of this new genre with postmodern reading. This study uses literature review as its method, grounding on theoretical discussions.

Key Words: Post-modernism, Artificial intelligence, Interactive drama, Cinema, Audience experience

\section{Atıf İçin / Please Cite As:}

Muratoğlu-Pehlivan, B. ve Türkgeldi, S. K. (2020). Post-modern dönemde senaristin ve izleyicinin rolü: Yapay zeka, interaktif drama ve sinemanın geleceğine dair bir öngörü. Manas Sosyal Araştırmalar Dergisi, 9(4), 26382652.

Geliş Tarihi / Received Date: 30.04.2020

Kabul Tarihi / Accepted Date: 13.08.2020

\footnotetext{
${ }^{1}$ Dr. Öğr. Üyesi - Antalya Akev Üniversitesi, Sanat ve Tasarım Fakültesi, İletişim Tasarımı Bölümü, bahar.muratoglu@akev.edu.tr ORCID: 0000-0001-8977-822X

2 Dr. Öğr. Üyesi - Çukurova Üniversitesi, İletişim Fakültesi, Radyo, Televizyon, Sinema Bölümü, kturkgeldi @gmail.com ORCID: 0000-0002-6465-923X
} 


\section{Giriş}

Bu çalışma; yeni iletişsim teknolojilerinin sağladığı olanaklar ile mümkün olan interaktif dramalardaki izleyici deneyimini ve söz konusu deneyimin yapay zekâ tarafindan üretilen senaryolarla sağlanmasının mümkün olup olamayacağını tartışmak ve bu tartışmayı post-modern dönemde sarsılan yazar otoritesi ve okuyucunun / izleyicinin aktif bir rol üstlenmesi bağlamında değerlendirmek amacıyla tasarlanmıştır. Böylelikle interaktif drama, yapay zeka ve izleyici deneyimi ile bu kavramların birbirleriyle ilişkileri tartışmasına bir katkı sağlanması amaçlanmıştır. Bu sebeple de literatür taraması yöntemiyle mevcut kuramsal tartışmalara yer verilmiş ve tartışmaların işaret ettiği noktalardan yola çıkarak değerlendirmeler ve öngörülerde bulunulmuştur. Buradaki tartsşmanın amacı, interaktif dramaların, klasik dramalardan etkileşimsel açıdan farklı bir deneyim sunması nedeniyle, günümüzde yaratıc1/yazar, okuyucu/izleyici mefhumlarını nasıl etkileyebileceğini felsefi düzlemde ele almaktır. Bu bağlamda post-modern olarak kavramsallaştırılan döneme dair gözlemlerde bulunan düşünürlerin fikirlerinden referans alınmıştır. Bugün dramanın yapısına (bugün için) sınırlı da olsa müdahale edebilen izleyici/katılımcıdan bahsedebiliyorsak ya da belirli algoritma eşliğinde dramanın yapısının izleyiciye göre değişebileceği örnekler mevcutsa bu doğrultuda yazarın/yaratıcının yerini nasıl düşünmeliyiz sorusu önem kazanır. Yaratıc1, algoritmayı tasarlayan mıdır? Yoksa izleyicinin yönelimlerine göre biçimlenen anlatıyı amorf bir hale getiren algoritmanın kendisi midir? Eğer anlatıya müdahale edebiliyorsa izleyici artık sadece bir izleyici midir? Yoksa anlatıya ikincil düzeyde de olsa katılan bir yaratıcı mıdır? Bu sorulara kesin bir cevap verebilmek bu çalışma sınırlarında elbette mümkün değildir. Buradaki amacımız, bu durumun ortaya çıarttığı muğlaklığa dair kavramsal bir tartışma yapmaktır. Bu tartışmayı daha belirgin ve düşünülebilir hale getirmek için ilk etapta post-modern dönemde yazar ve okuyucu / izleyici rolleri üzerine literatüre bakmakta fayda vardır.

Post-modern dönem, pek çok şeyde olduğu gibi, edebiyat çalışmalarında da yazar, metin ve okur arasındaki ilişkiyi derinden sarstı ve değiştirdi. Modern dönemde yazarın sahip olduğu iktidar ve metnin anlamını belirleme konusundaki yetkisi, post-modern dönemde ortadan kalktı ve okur, yeni bir iktidar sahibi olmasa da, metnin anlamı üzerinde söz söyleme hakkı olan yeni bir oyuncu olarak yükselişe geçti. Roland Barthes, bu durumu "Okurun doğumu, yazarın ölümü pahasına gerçekleşmelidir." sözüyle özetlemişti (Barthes, 1977, s. 148).

Modern dönemde yazarın elinde metnin anlamı konusunda bir otorite bulunurken; okurun görevi, yazarın niyetlerini anlamak ve metnin anlamını, söz konusu niyetler ışığında değerlendirmekti. Bu noktada da yazarın hayatının, yaşadığı dönemdeki toplumsal olayların ve siyasi durumun, yazarın niyetleri ve metnin anlamı konusunda belirleyici ipuçları sunduğu kabul ediliyordu. Oysa post-modernistler, yazarın metnin anlamını belirleme konusunda ayrıcalıklı bir rolü olmadığını, yazarllğın doğası gereği karmaşık olan yapisının buna izin vermeyeceğini öne sürdü (Rosenau, 2004, s. 51-52). Bu noktada post-modernistlerin, yazarın kendi niyetlerinin tam olarak ve kesin bir şekilde farkına varmasının mümkün olmadığını ifade ettiği düşünülebilir. Dolayısıyla yazar, metnin anlamı konusunda da kesin konuşma yetkisine sahip olmamalıdır. Metin, yazarın elinden çıktıktan sonra bağımsızlaşır ve okuyucunun yorumlarına açık hale gelir.

Aslına bakılırsa, edebi metinlerde yazarın ortaya çıkışı ve iktidar sahibi oluşu, tarihsel olarak her zaman modern dönemdeki gibi değildi. Örneğin Foucault (Foucault, 1998, s. 306), söz konusu metinlerin, 17. ve 18. yüzylla kadar bir yazara ihtiyaç duymadığını; hikayeler, destanlar ve halk masalları gibi metinlerin kim tarafindan yazıldığının sorgulanmadığını belirtmişti. 1600'lü ve 1700'lü yıllara gelindiğinde ise, edebi metinler bir yazara ihtiyaç duymaya başlamış ve şiir ya da kurgusal metinler, ancak yazarı belli olduğunda ve yazarına göre değer kazanmıştı.

Öte yandan, edebi metinler, yazı ve alfabe öncesi dönemde; sabit, her anlatıldığında aynı sırayı takip eden ve olay örgüsünün değişmediği metinler değildi. Dolayısıyla metin, okuyucu / dinleyici ile buluştuğunda ilk yaratıcısına değil, o anki anlatıcının yorumlarına bağlıydı ve değişkendi. Bu nedenle, sözlü kültürde, bugün bildiğimiz anlamda bir yazardan söz edilemezdi. Metinler, ancak yazıya geçirildiklerinde sabit bir zaman sıralaması ve olay örgüsü kazandı (Logan, 2014, s. 99-100). Barthes da (1977, s. 142) benzer bir şekilde, etnografik toplumlarda hikayenin sorumluluğunun, anlatıcı konumundaki aracıda olduğundan ve yazar diye tanımladığımız kişinin modern dönemde ortaya çıktığından bahsetmişti.

Bir başka deyişle metinler, her anlatıldığında, anlatıcıya ve anlatıcı - dinleyici etkileşimine göre değişebilen, yenilenebilen ve hareketli bir niteliğe sahip olan kolektif ürünlerdi. Buradan yola çıkarak, yazarın iktidarının tohumlarının, yazı ve alfabenin bulunmasıyla atıldığı, yazılı kültüre geçiş ve nihayet modernite ile de en yüksek noktasına ulaştı̆̆ söylenebilir. Yazı, metni ve hikayeyi sabitlemesi ve istediği 
biçimde muhafaza edebilmesi için yazara bir güç vermiş olur. Modernite ise söz konusu gücü, bir iktidara dönüştürerek metnin anlamı üzerinde yazara sınırsız bir yetki verir.

Ancak post-modern dönemde, yazarın otoritesi sarsılmış ve okurun, metni istediği gibi okuması ve yorumlaması için alan açılmıştır. Post-modernistler, söz konusu yorumların ve okumaların hiçbirini, bir diğerinden üstün kabul etmez ve herhangi bir okuru yeni bir otorite olarak görmez (Rosenau, 2004, s. 49). Şüpheci post-modernistler, okura tam bir özgürlük verir; hiçbir ölçüt olmadan, okurun metne istediği anlamı vermesine olanak tanır. Bütün okurlar eşittir ve hiçbir okuma diğerinden üstün değildir. Olumlayıc1 post-modernistler de okura benzer bir özgürlük vermekle birlikte, şüpheciler kadar büyük güçler vermezler (2004, s. 67).

Bauman'a göre de modern dönemde entelektüel ve yazar, bir yasa koyucu olarak işlev görmüş ve iktidar sahibi olmuştur. Ancak post-modern dönemde, söz konusu rol ortadan kalkmışır (2018, s. 147152). Yazarın artık yasa koyucu olmaması, metni onun boyunduruğundan çıkarmış olur. Böylece metin; her okuyucunun istediği gibi yorumlayabileceği, üzerinde herhangi bir otorite olmayan, serbest bir biçime bürünür. Bu durum da, metnin sabitlikten kurtularak, tekrar hareketli hale gelmesi anlamını taşır.

Barthes'a (1975) göre de okur, bilgiye ulaşmak yerine, okumanın verdiği haz için okur. Bu nedenle de, yazarın belirttiği sıraya göre veya yazarın istediği şekilde okumak zorunda değildir. Bu noktada Barthes'ın ifade ettiği post-modern okumanın, sözlü kültürlerde her anlatıldığında değişen ve belirli bir yazara sahip olmayan metinlere denk düştüğü söylenebilir. Hikâye, bir anlamda, yazarı öldürerek, yazı öncesi özgürlüğüne döner. Buna paralel olarak, post-modernistler, yazarın doğruyu aktarma iddiasına hiç girişmemesi gerektiğini, bu çabanın onu, deyim yerindeyse bir güç tacirine dönüştüreceğini ve otoriterleştireceğini iddia eder. Onlara göre önemli olan, okurun ve gösterenlerin "özgürlügü ve oyunculuğudur" (Kenway, 1995, s. 39).

Ayırca, yukarıda da belirtildiği gibi yazar, modernitenin bir ürünüdür ve buna ek olarak, postmodernistlere göre gelecekte yeniden yok olabilir (Rosenau, 2004, s. 54). Hikayeler, yazı öncesi özgürlüklerine ve hareketliliklerine geri dönerken, yazarı da tekrar ortadan kaldırabilir. Foucault da (1998, s. 314) "Kimin konuştuğunun ne önemi var?" sorusunu sorarak, benzer bir noktaya parmak basmıştır.

Çăğımızın en önemli düşünürlerinden Umberto Eco da, yazar, metin ve okur arasındaki ilişki üzerine post-modernistlere benzer bir yorum yapmış ve açık yapıt kavramılla, okura metnin anlamı üzerinde söz söyleme hakkı vermiştir. Eco’ya göre açık yapıtlar hareketlidir ve okuru ya da izleyiciyi eş-yaratıcı olmaya, yapıtı yazar ile birlikte yaratmaya davet eder. Açık yapıt, aynı zamanda, sonsuz sayıda okumaya izin verir (Eco, 1992, s. 34). Bu durum, Eco'ya göre bir oyundur ve yazar ya da sanatç1, okur ya da izleyiciye bir eser sunarak, onun kendi kültürüne, kendi kişisel eğilim ve beğenilerine göre eseri yorumlamasının ve esere yanıt vermesinin önünü açar. Burada, izleyici ya da yorumcu, eserle ilgili kendi biçimini oluştururken ve eseri yeniden düzenlerken, ona dayatılan bir diş zorunluluk yoktur (1992, s. 10-11).

Eco'nun açık yapit kavramına göre, yazar okuyucuya tamamlanacak bir metin sunar (1992, s. 34-42). Hatta, Eco, yazarın, yazmayı bitirdikten sonra ölmesi gerektiğini, böylelikle metnin yolunun önünü açacağını belirtmiştir (1983, s. 7). Açık yapıt kavramı, aynı zamanda okuyucuya biçilen pasif rolü de ortadan kaldırarak, onu etkin bir şekilde eserin yaratımında rol almaya davet eder (Rigel, 2010, s. 26). Böylelikle yazar, okur ve metin arasından çıkar ve ikisinin özgür bir etkileşim içerisinde bulunmasına izin verir. Yazar, ölerek - ya da ölmeyi seçerek - okura etkin olabileceği bir alan açmış olur. Bu, yazarın otoritesinden vazgeçişidir.

Eco, Paul Valery'nin "bir metnin hakiki bir anlamı yoktur" sözünü alıntılarken, Tindall'ın sanat yapıtlarının "yapıtın yaratıcısı da dahil olmak üzere, herhangi birinin inandığı gibi 'kullanabileceği' bir araç olduğunu" savunduğunu aktarır (Eco, 1992, s. 17). Eco'ya göre, okurun her yorumu, her okuması, diğer yorumlar için bir tamamlayıcılık işlevi görür. Okur, bir eseri yorumlarken, eser kendisi için o esnada tamamlanmıştır, fakat mümkün olan tüm yorumlar ve okumalar ortaya konulamadığından, eser aynı zamanda tamamlanmamıştır da (Eco, 1992, s. 27). Öyleyse bir yapıtın, tüm okumalarının toplamı olduğu söylenebilir. Okur, söz konusu okumaların içinde kendi yolunu çizerek ilerler.

Ayrıca Eco, bir yapıtın açık olmasının, ondan alınacak estetik haz için ön koşul olduğunu belirtir. Eserin yaratıcısının yapıtın açık olmasını hedeflememiş olması, bu durumu değiştirmez (Eco, 1992, s. 58). Ancak Eco, post-modernistler, özellikle de şüpheci post-modernistler kadar ileri gitmez ve okurun yorumunu kısıtlayan, ona metin üzerinde sınırsız yorum yapma yetkisi vermeyi engelleyen birtakım ölçütler olduğundan bahseder (2008, s. 54). Eco'ya göre, hangi okumanın daha doğru, daha iyi olduğunu 
belirleyemeyecek olsak bile, hangi yorumların ya da okumaların daha kötü olduğunu belirleyebileceğimiz ölçütler mümkündür (2008, s. 66). Örneğin, içsel tutarll1ık bu noktada önemlidir. Eco, metnin bir bölümünün belirli bir okuması, metnin başka bir bölümü tarafindan çürütüldüğünde, söz konusu okumanın reddedilmesi gerektiğini belirtir (2008, s. 81). Post-modern dönem; yazar, metin ve okuyucu ilişkisini dönüştürürken, genel anlamda drama, özel anlamda da sinema için de yeni kapılar açar. Bu bağlamda, izleyicinin aktif katıllımını öngören interaktif drama, günümüzde gittikçe gelişen ve yaygınlaşan bir alan olarak göze çarpar. Bu nedenle interaktif drama ve izleyici ile olan ilişkisi, aşağıda tartışılacaktır.

\section{İnteraktif Drama}

Interaktivite kavramını tanımlamak başlı başına zor olduğundan, interaktif drama kavramını tanımlamak da problemli bir hale gelmiștir (Bostan \& Marsh, 2012, s. 27). Bu nedenle, tartışmanın sınırlarının belirlenmesi için, öncelikle interaktivite kavramının genel çerçevesi çizilmelidir. Kavramın genişliği, onun pek çok farklı bağlamda kullanılabilmesine sebep olur. Farklı alanlar, farklı perspektiflerden ve farklı terimlerle ilişkili olarak interaktiviteyi tanımlamaya çalışmışır. Araştırmacılar da genellikle kavramın muğlaklığı, kavramsal zorluğu ve aşırı kullanımı üzerine odaklanmıştır. Bu çalışmada ise interaktivite kavramı, bir drama türünü nitelemek için kullanılacaktır. Ancak kavramın nasıl tanımlandığı ve dramaya ne gibi bir özellik kattı̆̆ı, tartışmamız açısından önemlidir.

Çok genel bir tanımlama da olsa, interaktivite kavramı aslında her türlü etkileşime gönderme yapar. Güncel açıdan bakıldığında ise, dijital medya teknolojileri ve çoklu-oyunculu oyunlar gibi birçok farklı alanda interaktivite kavramı karşımıza çıkar. Dolayısıyla, interaktivite kavramının, aslında içinde bulunduğumuz dönemin iletişim pratiklerinin çeşitli unsurlarını tanımlamak amacıyla kullanılan, güncel iletişim süreçlerinin doğasına gönderme yapan bir kavram olduğunu söyleyebiliriz. Steuer'e (1992, s. 84) göre interaktivite kavramını, kullanıcıların gerçek zamanlı olarak bir aracı tarafından sunulan içeriğe katılım sağlayabilmeleri ve onu geliştirebilmeleri bağlamında düşünebiliriz. Örneğin, çok-yönlülük, katılımcılık, senkronluluk, paylaşım gibi nitelikler, interaktif olabilmenin bazı koşullarıdır. Bir başka tanım ise interaktiviteyi, bir iletişim sürecinde katılımcının sürece etki edebilme derecesi ve yine bu iletişim sürecinde rollerin karşılıklı olarak değiştirilebilir olması olarak açıklar (Williams, Rice, \& Rogers, 1988, s. 10).

Rafaeli'ye (1988, s. 111) göre ise interaktivite; bir iletişim sürecinde, her üçüncü veya daha sonradan gelen iletinin, bir önceki iletiye ne kadar atıf yaptı̆̆1 ya da bir önceki iletiyle ne kadar bağlantılı olduğunu ifade eder. Rogers'a (1986, s. 13) göre ise yeni medyanın kitlesellikten uzaklaşması, kontrolün üreticiden tüketiciye geçmesi anlamına gelir. Bu açıdan bireyselleşmenin de interaktivitenin bir parçası olduğunu öne sürebiliriz, çünkü interaktif bir katılım her şeyden önce bireylerin tekil girişimlerini varsayar. Smith'e (1980, s. 22) göre de, interaktiviteye izin veren araçlar, bireylerin televizyon ve gazete gibi kitle medyas1 araçlarındaki pasif rollerinin aksine, süreç içerisinde daha aktif bir rol edinmelerine olanak sağlar.

Öte yandan Jensen (1998, s. 201), interaktivitenin, medyanın kullanıcının içeriğe etki etmesine ne kadar olanak tanıdığ ile ölçülebileceğini söyler. Crawford (2013, s. 28) ise interaktiviteyi, iki ya da daha fazla aktörün dönüşümlü olarak dinlediği, konuştuğu ve düşündüğü bir süreç olarak tanımlar. Ancak buradaki düşünme, konuşma ve dinleme eylemleri metaforik olarak ele alınmalıdır; çünkü bilgisayar insanların anladığı biçimde düşünmez, konuşmaz ve dinlemez.

Bütün bunlara bakarak, kavramın tanımında yer alan bazı temel noktalarda uzlaşı olduğunu ifade etmek mümkündür. Bunlardan ilki, iki yönlü veya çok yönlü bir iletişim süreci bulunması gerektiğidir. Bir diğeri; katılımcıların, mesajı yollayan ile mesajı alan șeklinde tanımlanan rollerinin değiştirilebilir olmasıdır. Ayrıca, çoğunlukla iletişim içerisinde bulunanlar, insan ya da bilgisayardır ve her ikisi de alıcı veya verici görevi görebilir. Bireyler, içeriği ve biçimi değiştirme yetisine sahip olmalı ve interaktivite sonucu ortaya çıan farklılıkları gözlemleyebilmelidir (Kiousis, 2002, s. 368)

Öte yandan, interaktivite kavramının anlamının sınırlarını belirlemek için, interaktif olan ilişkinin taraflarını tanımlamanın da gerektiği söylenebilir. Söz konusu faillerinin kim ya da ne olduğu, interaktifliğin de zaman zaman farklı tanımlanmasına neden olmuştur. Bu nedenle, interaktivitenin drama ile olan ilişkisini tanımlamadan önce, interaktivite kavramının farklı seviyeleri üzerine düşünülmelidir.

Bostan ve Marsh'a (2012, s. 26) göre, interaktivite kavramı ilk etapta kullanıc1 - kullanıcı ilişkisine gönderme yapan kişiler arası bir ilişkiyi niteleyebilir. İkinci olarak ise interaktivite, kullanıcı - içerik arası ilişkiye gönderme yapan, birey - içerik arası bir ilişki anlamına gelebilir. Son olarak ise interaktivite kavramı, kullanıcı - sistem arası ilişkiyi tanımlayabilir. Bu noktada interaktif ilisski, bunlardan herhangi biri olabileceği gibi, birden fazlasının bulunduğu bir ilişki biçiminde de oluşabilir. Video oyunlarının tarihine bakıldığında, 
interaktivite bağlamında birçok içeriğin üretilmiş olduğunu görmek mümkündür. Video oyunlarının bu denli fazla örneğe sahip olması, oyun konsollarının doğası gereği interaktif bir araç olması ile açıklanabilir. Bir araç olarak oyun konsolu, kullanıcının ekranda gördüğü oyuna ait öğelerle bir tür etkileşime girmesine olanak sağlar. Ancak bunun da ötesinde, video oyunu bir içeriğe de sahiptir ve oyuncunun bu içeriğe belirli bir ölçüde katılmasına izin verebilir. Hem oyuncunun konsolun kumandası aracıllğıyla sisteme bazı sinyaller göndermesi ve buna karşıllk sistemin buna bir tepki göstermesi, hem de oyuncunun görmekte olduğu hikayenin akışına müdahale edebilmesi birer interaktif ilişki biçimidir. Bunun yanı sıra, çokluoyunculu bir oyunda, oyuncular birbirleriyle etkileşim kurarak bir tür kullanıcı - kullanıcı düzeyinde interaktivite deneyimleyebilir. Görüldüğü gibi, bir ilişki olarak interaktivite, aynı anda farklı hallerin bir karışımı olarak da karşımıza çıkabilir.

Bu tanımlamalara bağlı olarak, genel anlamda bakıldığında interaktivite kavramının kullanıcı ve içerik arasındaki bir tür etkileşime gönderme yaptığını söyleyebiliriz. Bostan ve Marsh (2012, s. 27) interaktif dramayı, söylemin karşılıklı olarak inşa edildiği ve bir kontrol duygusu yaşatmak için, oyunun biçim ve içeriğinin gerçek zamanlı olarak dönüştürülüp oyuncunun isteğine göre biçimlendirilebildiği bir drama türü olarak açıklar. Szilas da (1999, s. 150) benzer şekilde interaktif dramayı, izleyicinin drama içerisindeki akışa müdahale edebildiği özel bir tür olarak tanımlar. Bu tanım, romandaki okuyucunun veya tiyatrodaki izleyicinin pasif olduğu anlamına gelmez. Burada da bir tür aktiflik vardır, ancak bu içsel bir aktifliktir. İnteraktif drama ise, katılımcının anlatının seyrine doğrudan müdahale edebildiği bir aktiflik olarak tanımlanabilir.

Laurel (1986, s. 9-11) interaktif dramayı, kullanıcının hayali bir dünya içerisinde yaptığı seçimlerin ve eylemlerin, olayların akışını etkilemesi olarak tanımlar. Burada kullanıcının hikaye oluşumuna doğrudan katılabileceği, buna ek olarak da sistem tarafindan oluşturulan olayların yönetilebileceği bir hikaye yazım programından bahsedilmektedir. Bu noktada interaktif dramanın temel prensipleri şu şekilde özetlenebilir: Birincisi dramanın, bir karşılıklılık üzerinden tanımlanan interaktif kavramının mantı̆ğına uygun olarak tasarlanmasıdır. Kullanıcı ve yapay zeka tarafindan yönlendirilen sistem arasındaki ilişki, taraflar arasında drama boyunca sürekli devam eden bir etkileșim ve işbirliği şeklinde vücut bulmalıdır. İkincisi, deneyimin kendisinin dramatik olması, diğer bir deyişle interaktif bir dramanın, kişinin klasik bir dramadan aldığı zevki sağlıyor olması gerekir. Kullanıcı, hayal dünyasında bir rol deneyimlerken, bir yandan da bir izleyici olarak dramanın yarattığı duyguları ve bu duyguların verdiği keyfi hissedebilmelidir. Kullanıcı ve drama arasındaki bu etkileşim, tekrarlara dayalı ve karmaşı olmaktansa, hikayeyi zirve noktasına ve daha sonra çözülmeye götürmelidir. Böylelikle kullanıcı deneyimi, bir yandan interaktiviteye dayalı bir özgürlük içerirken, bir yandan da dramatik yapısını korumuş olur (Mateas, 2002, s. 7). Bu noktada şunu belirtmek gereklidir: İnteraktif dramaların çoğu, öykünün gücünü azaltmaya, gerilimi düşürmeye eğilimlidir (Szilas, 1999, s. 150). Szilas'a göre klasik dramalarda bir tür kenetlenme mevcuttur. Esas olan, hikayenin bir yolculuk olmasıdır ve anlatı boyunca başına gelen şeyler, karakteri belirler. Ayrıca, karakterin yapmış olduğu yanlış seçimler ve çelişkili etik tutumları, hikayenin çatışmasını kuracak gücü içinde taşıyan unsurlardır. Hikayenin itici gücü, bir seçim meselesinden çok, söz konusu öğelerdir (1999, s. 151). Dolayısıyla interaktif dramanın, interaktivitenin bir unsuru olan etkileşimin ve dramanın bir unsuru olan kenetlenmenin dengeli bir şekilde inşa edildiği / edilmesinin gerektiği melez bir tür olduğunu söylememiz mümkündür.

Sinemada bilinen ilk interaktif drama denemesi, Çekoslavak yönetmenler Radúz Činčera, Jan Rohac ve Vladimir Svitacek'e ait, Montreal Expo 1967'de gösterimi yapılmış olan Kinoautomat: One Man and His House filmidir. Filmde, kendini sürekli ahlaki ikilemlere düşürecek olayların içinde bulan Bay Novak'ın hikayesi anlatılır. Filmin gösterildiği yer, seyircilerin oylama yapabilmesine olanak sağlayacak şekilde inşa edilmiş olan özel bir sinema salonudur. Bu salonda 124 kişiden oluşan bir izleyici kitlesine film sunulur. Salonun özelliği, koltuklarda izleyicilerin filmin karakterinin beş kritik noktada nasıl davranacağını oylamalarına imkân veren yeşil ve kırmızı butonların bulunmasıdır. Makinist, çoğunluğun verdiği karara göre bir sonraki sahneyi seçer. Böylece sinema tarihinde ilk defa, seyirciler, filmi izleme deneyimleri sırasında belirli noktalarda kendilerine sorulan sorulara karşlık, oylama yoluyla filmin hikayesine aktif olarak katılmış olurlar (Hales, 2005, s. 54).

1970 yllına gelindiğinde ise, James Meehan ve Roger Schank Tale-Spin’i geliştirir. Tale-Spin, genel anlamda karakterlerin davranış şekillerindeki rasyonaliteyi simüle ederek anlatı kuran bir yazılımdır. Programda ana amaç ve ana amaca ulaşmak için aşılması gereken alt-amaçlar için bir problem çözücü bulunur. Ayrıca, çıkan sonucu belleğe gönderen ve bu bilgi ile yeni savlar üreten bir sav mekanizması da vardır. Hikâyenin geçtiği dünyanın o anki görünümünün nasıl olduğu ve karakterler arasındaki sosyal 
ilişkiler gibi bilgiler de, yeni savlar oluşturulurken kullanılır. Son olarak, üç farklı olayı birbiri ile bağdaştırıp sonuç üreten bir bağdaştırma mekanizması da mevcuttur. Bu sayede Tale-Spin, dairesel bir biçimde kendi içinde hikâye üreten bir yap1 kurar (Meehan, 1977, s. 91).

1984 yllında ise Lebowitz, Universe adını verdiği interaktif bir hikâye anlatma prototipi geliştirir. Universe, olay örgüsünün çerçevesini çizmek için küçük hikaye parçaları ve belirli olasılıkları kullanan bir hikaye anlatım programıdır. Kullanılan hikaye parçaları ve karakterler için Universe ün oldukça geniş bir havuzu bulunur ve bu sayede çok çeşitli olay örgüleri yaratılabilir (Lebowitz, 1985, s. 483-502).

2006 yllına gelindiğinde, Michael Mateas ve Andrew Stern, Façade adında bir interaktif hikaye anlatma yazılımı geliştirmişlerdir. Façade'da kullanıcı, 30'lu yaşlarında evli bir çiftin eski bir arkadaşı olarak oyuna girer. Kullanıcı çiftin evindeyken, karı-kocanın evliliklerindeki sorunlar ortaya çıkar. Kullanıcı da bu tartışmaya dahil olur ve olayın nasıl sonlanacağını, vermiş olduğu geri dönüşsüz kararlarla belirler (Matteas, 2006, s. 3).

2016 yllında CtrlMovie tarafindan geliştirilen, yönetmenliğini Tobias Weber'in, senaristliğini ise Michael R. Johnson'ın yaptı̆̆1 Late Shift filmi yayınlanmıştır. Film, oyun konsollarına yönelik olarak üretilmiş bir filmdir. Filmin karakteri, Londra'nın yeraltı çeteleri tarafindan bir tür soygun olayına dahil edilir. İzleyiciler filmin belirli anlarında, hikayenin farklı sonlarla bitmesine neden olacak kritik seçimler yapar.

Benzer bir örnek olarak, 2018 yilında Netflix tarafindan yayınlanan Bandersnatch de, sinemanın yeni medya teknolojilerinin getirdiği olanaklar sayesinde interaktif olarak deneyimlenmesinin önemli örneklerinden biri olarak gösterilebilir. Bandersnatch de Late Shift gibi kullanıcıların / izleyicilerin belirli sahnelerde kendilerine sunulan iki seçenekten birini tercih ederek hikayenin akışına yön verdiği bir interaktif dramadir.

Diğer yandan, Late Shift ve Bandersnatch gibi oyun şeklinde dizayn edilmemiş olan interaktif dramaların çoğalmasının, PC ve konsol gibi platformlar için üretilmiş olan oyun formatlı interaktif dramaların son yıllarda daha sık üretilmesi ile ilişkili olduğu söylenebilir. Örneğin David Cage, bu anlamda azımsanamayacak sayıda anlatının yaratıcıllğını üstlenmiştir. 2005 yılında Fabreneit, 2006 yllında Heavy Rain, 2013 yilinda Beyond Two Souls, 2018 yilında ise Detroit: Become Human, Cage tarafindan tasarlanmıştır. Bu oyunlar her ne kadar bir sinema örneği olarak ele alınmasa da, sinematografik tekniklerin oldukça yoğun bir şekilde kullanılması, kullanıcı deneyimini özellikle görsel açıdan bir film deneyimine yaklaştırır.

Geçtiğimiz 40 yıllık süreçte, interaktif drama denemeleri giderek çoğalmıştır. Bugün interaktif dramalar, video oyun dünyasının, hatta son zamanlarda sinema dünyasının bile dikkat çekici bir eğilimi olarak karşımıza çıkar. Ancak, burada bir ayıım yapmamız faydalı olacaktır. Oyun konsollarında, özellikle son yllarda birçok interaktif drama popüler hale gelmiştir. Bunda oyun konsollarının teknolojik altyapısının, dramaya interaktif bir katılıma izin vermesinin, kuşkusuz büyük bir rolü vardır. Gelgelelim, ilk bakışta sinema deneyimi interaktif bir katılıma müsait değil gibi görünür. Eğer sinemayı, sinema salonunda gerçekleşen, mekânsal bağlamda kamusal bir deneyime indirgersek, bunun doğru bir gözlem olduğu söylenebilir. Ancak artan olanaklar, kişisel bilgisayarlar, akıllı TV'ler, tabletler ve konsollar vasitasıyla Netflix gibi mecraların ortaya çıkışı, sinema deneyimini kamusal alandan bireysel alana transfer edebilir ya da en azından bu noktada ciddi bir alternatif oluşturabilir. Bu bağlamda, günümüzde sinemanın en azından deneyimlendiği platform bağlamında belirli bir açıdan bir video oyunu gibi de tüketilebilen bir ürün haline gelebilmiş olması, dikkat çekici bir noktaya işaret eder.

Peki interaktif drama, izleyiciye nasıl bir deneyim sunar? İnteraktif dramanın hikaye anlatım biçimi, bir gün doğrusal hikaye anlatımının yerini alabilecek ve sinemayı dönüştürebilecek bir potansiyele sahip midir? Bunu anlamak için, interaktif dramada izleyici deneyimi üzerine düşünmek gerekir.

\section{İnteraktif Drama ve İzleyici Deneyimi}

Dramanın doğrusal yapısı, interaktif dramalarla birlikte çizgisel olmayan bir forma bürünür. İnteraktif drama, her şeyden önce, izleyiciye seçim hakkı verir ve bu anlamda da yazarın otoritesini sarsar. Aslında bu anlatı biçiminin en önemli yönü, izleyicinin artık bir izleyiciden ziyade bir tür katıllmcıya dönüşmüş olmasıdır. Bu durum, drama söz konusu olduğunda oldukça önemli bir dönüşüme işaret eder. Çizgisel anlatıda bir yazar olarak senarist, anlatının ilerleyeceği doğrusal rotanın yaratıcısı olarak karşımıza çıkar. Öte yandan interaktif bir anlatıda, yazar olarak senaristin / yaratıcının yaptı̆̆ şey, anlatının farklı hatlardan ilerleyebilmesini sağlayacak çeşitli alternatif patikaların tasarımını yapmaktır. Bir katılımcı olarak izleyici ise, bu alternatif patikalar üzerinden kendi seçimlerine dayanan bir anlatının ikinci yaratıcısı haline gelir. Bu 
anlamda interaktif drama, bir post-modern anlatı türüdür. Senarist, artık hikaye üzerinde tek karar verici değildir. Burada, yazarın metinle olan ilișkisindeki değișim, okuyucunun da metinle olan ilișkisinde bir dönüşüme neden olur. Bu aşamada, izleyicinin katılımını yaratım sürecinin bir parçası olarak değerlendirmek, izleyiciye gereğinden fazla anlam yüklemek gibi gözükebilir. Ancak șunu hatırlatmakta fayda vardır; izleyici artık pasif değil, hikayenin gidişatı içerisinde kendisine göre seçimler yaparak anlatının yönünü belirleyebilen, sadece içsel olarak aktif değil dışsal açıdan da aktif bir konuma geçmiştir.

Bu noktada interaktiflik, sinema anlatısı bağlamında nasıl düşünülmelidir? Bir filmle olan ilişkimiz; ekranla kurduğumuz sinematografik özdeşlik bir yana, anlatının kendisiyle kurduğumuz ilişkiyi de kapsar. Anlatıdan duyduğumuz hazzın derinlerinde ise, karakterlerle kurduğumuz ilişkiler yer alır. İzleyici, karakterlerin eylemlerine bağlı olarak anlatının hattında yol alır. İnteraktif dramanın doğasında ise, sinemanın ve hatta anlatı sanatının zemininde var olan temel bir durumun değişmesi söz konusudur. Bir metnin ya da dramanın aktif bir katılımcısı olmak, karakter ile olan bağı sarsar ve kimyasını dönüșüme uğratır. Anlatıdaki olaylara müdahale edemeyen seyircinin yerine, anlatıya müdahale eden ve onu kendi kararları doğrultusunda düzenleyen bir katılımcı gelmiştir. Oysa klasik dramanın çekici yanı, önemli ölçüde hikâyenin nasıl ilerleyeceği ile ilgili merak duygusudur. İnteraktif dramada merak duygusunun yok olduğunu söyleyemeyiz. Ancak, hikâyenin nasıl ilerleyeceği üzerine tahmin yürütmek ve hikâye üzerine içsel tahminlerde bulunmak bir hayli zordur; çünkü artık elimizde ne olacağını tahmin etmeye çalışan izleyici değil, ne yapacağına odaklanan ve doğru kararı vermeye çalışan bir katılımcı rolü vardır.

Bu durum, bir yolda ilerlemekte olan aracın yolcusu olmakla sürücüsü olmak arasındaki farka benzer. Yolcu, yolu izler ancak aracın gidişatına müdahale edemez. Sadece bazı beklentilere sahip olabilir. Bu bir seyretmedir. Sürücünün seyredişi ise farklıdır. Sürücü daha ziyade, bir sonraki hamlesini ve aracı nasıl kullanması gerektiğini düşünür. Buna göre karar alır ve kontrol sağlar. Dolayısıyla, yolcunun yolla kurduğu ilişki ile sürücünün yolla kurduğu ilişki birbirinden farklıdır. Bu yüzden Baudry'nin (1974) büyüleyici regresyon olarak tarif ettiği ekran ve izleyici ilişkisi, interaktif dramanın bu farklı seyir haline pek uyum sağlamaz. Benzer şekilde, Aristoteles’in (M.Ö.335/2017) drama yapısından alınan haz, izleyicinin karakterle özdeşleşip bir katharsis yaşaması ile doğrudan ilişkilidir. İzleyicinin karaktere eklemlenip onunla sempatik bir bağ kurması yerine, doğrudan karakterin kendisi olmaya başlaması, dramatik yapı ile olan etkileşimi değiştirecektir. Peki söz konusu geçiş, izleyicinin / katılımcının hikayenin büyüsüne kapılmasını engeller mi? "Şimdi ne olacak?", "Karakter başına gelecekten haberdar mı?" gibi sorular; izleyicinin dramanın gerilimini yaşamasını sağlayan, hatta bir ölçüde drama deneyimini arzu etmesinin altında yatan bir tür ihtiyaç olarak görülebilir. Dahası, insanların hikayelere tam da bu yüzden ihtiyaç duyduğu söylenebilir. Klasik drama bu noktada interaktif dramadan daha farklı bir konumdadır. Sırf bu bağlamda bile ikisinin birbirini ikame edeceğini bugün için söylemek pek mümkün değildir.

Ancak, interaktif dramada merak unsurunun tamamen ortadan kalktı̆̆1 söylenemez. İzleyici halen, yaptığ1 seçimin sonuçlarının neler olacağına, hikayenin gidişatını nasıl etkileyeceğine ve bir sonraki seçiminde neyle karşılacağına yönelik merakını korur. Ayrıca, izleyici seçimlerini yaparken, hikayeye dair bilmediği pek çok şey hala var olabilir ve gizem duygusunu yaşamaya devam edebilir. Burada değişen şey belki, karakterin başına neler geleceğine yönelik merakın, izleyicinin kendisinin başına geleceklere dair bir meraka çevrilmiş olmasıdır. Bu durum ise, hikayenin heyecanının korunmasını sağlayabilir.

Öte yandan interaktif drama, izleyiciye, yaptığı seçimlerden vazgeçebilme, kararlarını geçmişe yönelik olarak değiştirebilme ve olay örgüsünün akışını tersine çevirebilme olanağı sunar. Interaktif drama sayesinde, gerçek yaşamda başaramadığımız ve imkansız olan bir şeyi yapabilme olanağını yakalarız: Geçmişe döner ve farklı bir seçim yaptığımızda neler yaşayacağımızı, hayatın nasıl olacağını görme şansı buluruz. Bir değil, birçok hakkımız vardır ve pişmanlıklarımızı giderebilir ya da seçmediğimiz yolların sonucunun nereye çıkacağına yönelik merakımızı tatmin edebiliriz. Milan Kundera, Varolmanın Dayamılmaz. Hafifliği adlı eserinde, şöyle söyler:

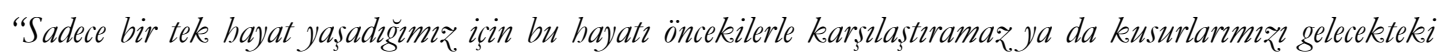

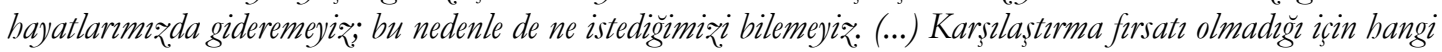
kararn daha iyi olduğunu sinamann bir yolu yok. Olaylar nasil gelisirse öyle yasyyoruv, önceden uyarlmaksız̨n, rolünü ezberlemeden sabneye ģkan bir tiyatro oyuncusu gibi. Yaşam öncesi ilk. prova yasamm ta kendisiyse, ne değeri olabilir yaşamanm? Yaşamm hep bir taslak gibi olmast da bundandir işte. Yok, 'taslak' da tam anlatamiyor dernek istedigimi, çünkü taslak bir seyin ana çizgileriyle belirmesi demektir, bir resmin az.

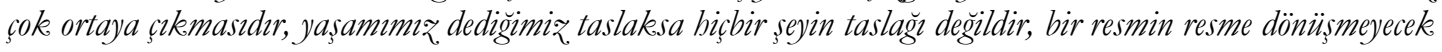
ana çizgileridir." (Kundera, 2007, s. 16). 
İşte interaktif drama, bizi yaşamın bu kısıtlamasından geçici bir süreliğine uzaklaştırır ve zamanın geri dönülemezliği yasasından sanal bir dünyada kurtulmamıza olanak sunar. Bu anlamda, tatmin ettiği istek; sonuçlarına katlanmak zorunda olmadan daha cesur ve özgür seçimler yapabilme, geri dönüp kararlarımızdan vazgeçebilme ve bizim için en iyi sonuca ulaşana kadar seçimlerimizi değiştirebilme yetisidir. Ayrıca izleyici, yine gerçek hayattakinin aksine, hikayenin nasıl biteceğine karar verebilir ve hikaye için istediği sonu seçebilir.

Dolayısıyla interaktif dramanın izleyiciye sağladığı tatmin, klasik dramanınkinden farklıdır. İzleyici, doğrusal dramadaki merak duygusunu belki bir ölçüde yitirir ve aynı derecede yaşayamaz. Karar verici rolü, belki, seçimleri üzerinde düşündüğü için kendini hikayenin akışına tam olarak kaptırmasına engel olur. Ancak bu, izleyicinin dramadan aldığı hazzın engellendiği anlamına gelmez, sadece farklılaştı̆̆ anlamına gelir. İzleyici bir anlamda, gerçek yaşamın kısıtlamalarından kurtularak seçim yapma özgürlüğüne sahip olmanın tatmini yaşar.

Diğer yandan, yukarda edebi metinlerin yazı ve alfabe öncesinde sabit olmadı̆̆ından ve her anlatıldığında, anlatıcısının yorumuna göre değiştiğinden bahsetmiştik. Bu anlamda interaktif dramanın, her izleyiciye göre değişen ve sabit olmayan anlatısı, aslen bir geçmişe dönüştür. Benzer şekilde, 17. ve 18. yüzyıla kadar da edebi metinlerin bir yazara ihtiyaç duymadığından da söz etmiştik. Dolayısıyla yazarın iktidar olması ve hikayelerin sabit bir biçime bürünmesi, düşündügümüz gibi hikaye anlatımının doğası değil, modern dönemin bir eseridir. Bu nedenle, post-modern dönem içerisinde yazarın yeniden yok olacağı, hikayelerin sabitlikten çıkıp değişken bir hale bürüneceği ya da destanlar ve efsaneler gibi kolektif bir ürün haline geleceği ihtimalinden söz edilebilir. Belki de hikaye anlatımının doğası aslen, otoriter bir yazar ve sabit bir metin içermez; dönüşüme izin veren ve hareketli bir yapı barındırır.

Her ne kadar hikaye anlatımı geçmişte benzer süreçler yaşamışsa da, post-modern dönemde interaktif drama ve yazarın otoritesinin zedelenişi, teknoloji ile bambaşka bir boyut kazanmıştır. Yapay zeka; gerek izleyicilere seçimler sunarak, gerekse de anlatıy kendisi oluşturarak, izleyicinin drama deneyimini dönüşüme uğratabilir. Ayrıca, interaktif drama açısından bakıldığında, izleyiciye seçmesi için çok daha fazla seçenek ve patika sunabilir. Burada tartışılması gereken konu, yapay zekanın yaratıcı potansiyelinin boyutları ve senaristi devre dışı bırakacak noktaya ulaşıp ulaşamayacağıdır.

\section{Yapay Zeka ve Senaristin Ölümü}

\section{Yapay Zeka ve Yaratıcılik}

İnternaktif olsun veya olmasın, yapay zeka tarafindan bir hikaye oluşturulması üzerine sorulabilecek en temel sorulardan biri, yapay zekanın yaratıcılığı üzerinedir; çünkü bir yapay zekanın verili bir olay örgüsü olmadan hikaye anlatması için, en azından bir dereceye kadar "yaratıcı" olması beklenir. Peki yapay zeka, insan zihninin yaratıcılığına erişebilir mi? İnsanın yaratıcllğını taklit eden bir yapay zeka mümkün müdür? Yapay zekanın üretimlerine yaratıcılık diyebilir miyiz? Bunlar, alanda uzun yıllardır tartışılan ve henüz kesin bir cevabı verilememiş sorulardır.

Alanın en önemli düşünürlerinden biri Margaret A. Boden de (2009, s. 347), yaratıcıllk konusunun, yapay zeka için önemli bir zorluk olduğunu belirtir. Boden'e göre yaratıcı bir fikir, “yeni, sürprizli ve değerli (ilginç, kullanışlı ve güzel)" olmalıdır. Peters da (1998, s. 836) zeka ve yaratıcılık ilişkisinden bahsederken, aynı şekilde, beklenmeyen, yeni ve sürprizli bir keşfin önemini vurgular. Peters, yaratıcılık konusunda sürpriz faktörünün üzerinde özellikle durur. Peters’a göre bir yapay zekay1 yaratıcı olarak tanımlamamız için, sürprizi algılayabilen ve ayırt edebilen bir yapıda olması gerekir. Sürpriz kavramının ortaya çıkabilmesi için ise, belirli bir beklenti ve o beklentiden bir sapma var olmalıdır. Beklenti, daha önceki deneyimlerimize göre şekillenirken; sapma, beklentiyle gerçekten olan arasındaki farktır (Peters, 1998, s. 837).

Bir başka deyişle, kodlama sonucu standart üretimler yapan bir yapay zekanın, her ne kadar hikaye üretebilse ve anlatabilse de, yaratıcı olduğu söylenemez. Verili kalıplar ve standart olay örgüleri, yapay zekanın üretim yapmasını elbette sağlayabilir; ancak söz konusu üretim, kimseyi şaşırtmayan, rutin ve ilerleyişi rahatıkla tahmin edilebilir bir hikaye ortaya çıkaracaktır. Oysaki yaratıcılıkla ilgili yukarıdaki tanımların ortak özelliği; daha önce düşünülmemiş, beklenmedik ve sürpriz içeren üretimlere atıf yapmasıdır. Dolayısıyla, tartışılması gereken en büyük soru, yapay zekanın beklenmedik ve alışılmışın dışında hikayeler anlatıp anlatamayacağıdır; çünkü eğer bu gerçekleşmezse, yapay zeka tarafindan oluşturulan hikayeler, hiçbir zaman sinema için yeterli olmayacaktır. 
Benzer şekilde Gervas da (Gervás, 2009, s. 49). yaratıcllıktan söz ederken, yeni, beklenmedik ve başkalarının ürettiklerinden farklı bir üretimin gerçekleşmesine atıf yapar. Gervas'ın üzerinde durduğu başka bir önemli nokta, üretim sürecinde bir aktör, yani bir yaratıcı olmasıdır. Söz gelimi, bir günbatımında da beklenmedik renkler ya da görüntüler ortaya çıkabilir, ancak burada yaratıcılıktan bahsedilemez.

Dolayısıyla burada ortaya çıan mesele, yapay zekayı bir özne ya da bir aktör olarak görüp görmeyeceğimizdir. Yapay zekanın yaptığı üretim, kendisine mi aittir, yoksa kodlayıcısına mı aittir? Hatta, söz konusu üretimin belirli bir yaratıcısı var mıdır? Yapay zekayı özne olarak kabul edeceksek, çizgiyi nerede çekmemiz gerekir? Bir başka deyişle, en basit programlar da birer özne midir, yoksa sadece belirli bir gelişmişlik seviyesinin üstünde mi birer aktör olarak kabul edilirler? Söz konusu gelişmişlik seviyesi nedir?

Bu sorulara paralel bir şekilde, Jennings'e göre (2010, s. 490-500) bir yapay zekanın üretim esnasında ortaya çıkan yaratıcllğın, kendisini kodlayan ve yöneten kişinin yaratcıllğının bir uzantısı olarak görülmesi gerektiği tartışlagelmiştir. Sonuç olarak yapay zeka, kendisini programlayan kişinin çırağı gibidir ve onun yaratııılık anlayışına bağımlı kalır. Bir yapay zeka, kendi başına neyin değerli ya da ilginç olduğuna dair fikirler üretme seviyesine gelemiyorsa ve bağımsız olarak standartlarını değiştirip programcının niyetlerini aşamıyorsa, yaratıcılık anlamında temel bir ilerleme sağlanamamış olur. Jennings, bunu başaran yapay zekanın yaratıc öz̧erklik sahibi olduğunu söyler. Ayrıca, söz konusu özerkliğin ortaya çıkabilmesi için, yapay zekanın sadece bir programcıyla iletişim halinde olmaması gerektiğini, birçok farklı yaratıcı ve eleştirmen ile etkileşimin gerekli olduğunu belirtir.

Burada bahsedilen "yaratıcı özerklik", belki, yapay zekanın bir özne olarak kabul edilmesi için gerekli sınırı işaret ediyor olabilir. Eğer yapay zeka yaratıcı özerkliğe sahipse, hem programcısının standartlarını aşabilir, hem de yeni ve daha önce düşünülmemiş fikirler (ve dolayısıyla sürprizler) ortaya koyabilir. Böylece de programcıdan bağımsız davranarak bir aktör haline gelir ve dolayısıyla gerçek bir yaratıcılık gösterebilir.

Boden (1998, s. 348) ise, yaratıcıllğı üçe ayırır. Bunlardan ilki, bileşimsel yaratıchlktır ve bilinen fikirlerin, daha önce düşünülmemiş ve yeni kombinasyonlarından, bağlantılarından oluşur. Betimlemeler ve analojiler, bu tür bir yaratıclık içerisinde değerlendirilebilir. Burada olan şey (2009, s. 24), bilindik fikirlerin, farklı bir şekilde bir araya getirilmesidir. Öte yandan ikinci yaratıclık türü, keşifsel yaratıcllktır ve Boden (1998, s. 348) bu türü, yapılandırlmış kavramsal alanlarla ilgili olarak tanımlar. Burada, beklenmedik fikirler ortaya çıkar, ancak bilinen düzenin dışına çıkılmaz. Bir başka deyişle (2009, s. 25), bilindik ve kabul edilmiş bir düşünce sistemi kullanılır ve alanla ilgili üretimin genel kurallarına uyulur. Boden (2009, s. 38; 1998, s. 25) son olarak dönüsï̈msel yaratıclhktan bahseder. Bu yaratıcilık türünde, alandaki temel belirleyici boyutlar dönüşüme uğratıllır ve dolayısıyla daha önce ortaya çıkması mümkün olmayan yeni fikirler ortaya çıkar.

Buradaki temel sorun, yapay zekanın dönüşümsel bir yaratıcllık gösterip gösteremeyeceğidir. Pek çok kişi, yapay zekanın sadece kendine söyleneni yaptığını, verili biçimler içerisinde üretim yapabileceğini; ancak yeni bir biçim yaratma veya biçimleri ya da kuralları dönüştürme gücüne sahip olmadığını söyler (Boden, 2009, s. 29). Boden'in dönüşümsel yaratıcllık kavramı, yaratıcı özerklik ile paralel olarak düşünülebilir; çünkü programcıdan bağımsız üretim yapabilen ve standartlarını değiş̧tirebilen bir yapay zeka, belirli boyutları dönüşüme uğratma ve böylelikle daha önce yapılması mümkün olmayan üretimleri ortaya koyma başarısı elde edebilir ve böylelikle de bağımsız bir aktör haline gelebilir. Isşte bu noktada yapay zekanın, senaristin yerine geçip geçemeyeceği tartışması gündeme gelir.

\section{Yapay Zeka ve Senaristin Ölümü}

Yukarıda tartısılan interaktif drama, her ne kadar yazarın yasa koyucu rolünü sarssa da, yazarın kendisini tamamen ortadan kaldırmaz. Peki ya gelecekte, yazarın gerçek anlamda var olmadığı bir anlatı türünü deneyimleme ihtimalimiz var mıdır? Örneğin yapay zeka, bireylerin tercihlerine göre bir senaryo yazabilir ve bu senaryonun içerisinde sonsuz ihtimaller denizi içinden izleyicinin seçim yapmasına izin verebilir mi? İşte böyle bir durum, gerçek anlamda yazarın ölümünden ve okurun doğumundan bahsetmemiz anlamına gelir. Ancak bunun için de, yapay zekanın yaratıcılığının, insan yazımı senaryonun yerini alabilecek kadar gelişmesi gerekir.

Günümüzde senaryo yazımında yapay zeka denemelerine rastlamak mümkündür. Örneğin, kendine Benjamin ismini veren bir yapay zekanın yazdığ iki senaryo, filmleştirilmiş ve izleyiciye sunulmuştur. New York Üniversitesi'nde yapay zeka araştırmacısı olan Ross Goodwin ve yönetmen Oscar Sharp tarafından geliştirilen Benjamin, oldukça tuhaf ve alısıllmadık senaryolar yazmıştır. Bu senaryolarından ilk olarak 
Sunspring isimli bir kısa bilim kurgu filmi çekilmiş ve bu film, 2016 senesinde, Oscar Sharp'n yönetmenliğinde piyasaya sürülmüştür. 2017 senesinde ise, ana karakterin çöküşü üzerine kurulu It's No Game, yine Sharp'n yönetmenliğinde izleyiciyle buluşmuştur (Fossa, 2017, s. 191-192). Benjamin geliştirilirken, pek çok bilim kurgu filminin senaryosu sistemine yüklenmiş ve böylelikle, bu senaryolardan yola çıkarak kendi olay örgüsünü oluşturması sağlanmıştır (Guardian, 2016).

Elbette ki yapay zeka henüz, insan yazımı bir senaryoda var olan yaratıc1lı̆ga sahip değildir ve senaristin yerine geçebilecek seviyeye henüz ulaşmamışır. Örneğin Benjamin isimli yapay zeka, farklı bilim kurgu senaryolarından yola çıkarak kendi hikaye örgüsünü oluşturmuştur. Peki bu durumda Benjamin'in yaratıcı özerkliğe sahip olduğu veya dönüşümsel bir yaratıcılık gösterdiği söylenebilir mi? Burada gördüğümüz şey, daha çok bileşimsel yaratıcıllğa veya en fazla keşifsel yaratıcilığa denk düşer. Bu sınırların aşılması, yapay zekanın insanın yerini alabilmesinin önündeki en büyük engel olarak görülebilir.

Öte yandan hikaye anlatımı, insan üretimi olduğunda dahi pek çok kez keşifsel yaratıcılığın sınırları dahilinde kalır. Dönüşümsel yaratıcılık, pek az eserde ortaya çıkan ve insanların da ulaşmakta zorlandığı bir aşamaya tekabül eder. Sinemada öncü olan, yeni bir hikaye anlatım tarzı geliştiren, alanın geleceğini dönüştürme gücüne sahip ve kült statüsünde pek çok yapıttan bahsedilebileceği gibi; bilindik hikaye anlatım tekniklerinin sınırları dahilinde kalan, öngörülebilir ve standartların dışına çıkmayan eser sayısı da oldukça fazladır. Dolayısıyla, izleyicinin çoğunlukla bileşimsel ya da keşifsel yaratıcılık örnekleriyle karşılaştı̆̆ını söylemek çok yanlış olmayacaktır.

Sinemanın klasik örneklerinin, belirli anlatı kalıplarının ve kurallarının çeşitli kombinasyonları olduğu söylenebilir. Çok genel olarak bakıldığında, bunların Campbell’n (2013) Kabramanın Yolculuğu olarak nitelediği mitolojik anlatı kalıpları ile oldukça ilişkili olduğu görülür. Kahramana ulaşan bir çağrı, bu çağrının reddi ya da kabulu ile çıkılan yeni bir yol, çatışmanın giderek tırmanıp doruğa ulaşması, hikayenin bir sona varması ile ortaya çıkan yeni durum ve düzenin yeniden tahsis edilmesi, diğer anlatı sanatlarında olduğu gibi sinemada da en sık kullanılan yöntem olmuştur. Ancak tarihsel açıdan sinemada bu yöntem ve onun çeşitli kombinasyonları, popüler kültür, sinema endüstrisi ve birçok başka değişken bağlamında sürekli evrilmiş ve kılık değiştirerek karşımıza çıkmıştır. Yine de, Hollywood tarihi boyunca büyük oranda filmlerin anlatı mekanizması bakımından birbirlerinden çok büyük farklarla ayrıldıkları söylenemez. Ancak burada esas mesele, yukarıdaki yaratıcılık sınıflandırması bağlamında, dönüşümsel yaratıcılığın sinemada ne gibi örneklere tekabül edebileceğidir. Örneğin, sinema tarihi içerisindeki avantgard ve sürreal denemeler, Fransız Yeni Dalga'sı gibi hem anlatısal hem de sinematografik açıdan geleneksel metotlara karşı duran akımlar, bu açıdan belirgin bir örnek teşkil eder. Bu tip dönüşümsel güç taşıyan eserler ortaya çıkaran akımlar; estetik, politik, ekonomik ve bunun gibi birçok farklı beşeri motivasyonla ortaya çıkmış ve bir süre sonra sona ermiş olsa da, etkileri kendisinden sonra gelen eserlerin yaratım sürecine sızabilmiştir. Birçok kişiye göre, daha önce de belirtildiği gibi yapay zekanın bu ölçüde bir dönüşümsel gücü içinde barındırıp barındıramayacağı sorusu, insan ile yapay zeka arasındaki en keskin ayrım noktasına tekabül eder. Ancak aynı yapay zekanın, örneğin belirli kombinasyonların algoritmik bir tasarımı ile çeşitlenebilen bileşimsel ve keşifsel düzeyde bir yaratıma ulaşması, bugün bile çok gerçek dışı gözükmez.

Peki bir gün yapay zeka, insan üretiminden ayırt edilemeyen senaryolar yazmaya başlarsa ne olur? İstenildiği anda, tercih edildiği şekilde senaryolar üretebilen ve bunları görselleştirebilen bir yapay zekanın varlığı, sinemayı nasıl etkiler? Böyle bir yapay zeka, interaktif drama için ne anlama gelir? Burada bahsettiğimiz yapay zekanın; kullanıcının o an seçtiği tür, mekan ya da karakterlere göre anında senaryo üretebilen; ürettiği senaryoyu hızlı bir şekilde görselleştirebilen; izleyiciye / katılımcıya istediği noktalarda hikayenin gidişatı ile ilgili karar verebilme olanağı sunan ve bu kararlara dayanarak sonsuz sayıda yeni patikalar ve hikaye örgüleri ortaya çıkarabilen bir yapıya sahip olduğunu varsayalım. Bu durumda hikayenin yazarı kimdir ya da belli bir yazarı var midır?

Böyle bir varsayım, izleyicinin / katılımcının eş-yaratıcı olacağı ve pasif konumundan çıkarak aktif hale geleceği bir öngörüyü içerir. Öte yandan bu durum aynı zamanda, bildiğimiz anlamda yazarın da ölümü demektir. Dolayisıyla, hikayenin belirli bir senaristi yoktur. Kat1lımc1, hem izleyici hem de bir tür yazar olarak deneyime katılır. Bu deneyimde, hikaye üzerinde izleyicinin kendisinden daha büyük bir otorite yoktur ve bu nedenle de izleyici bir yasa koyucu ile karşı karşıya değildir.

Öte yandan, yapay zeka sadece interaktif senaryo üretmek zorunda değildir. İzleyicinin isteğine; seçtiği konuya, karakterlere ve türe göre, doğrusal anlatılar da oluşturabilir. Böylelikle de izleyici, istediği tarzda bir filmi anında yapay zekaya ürettirerek, bir yandan hikaye üzerindeki aktif konumunu korurken, bir yandan da doğrusal anlatıdan aldığı deneyimi yaşamış olur. 
Böyle bir dönüşümün dirençle karşılaşacağını ve pek çok kişi tarafindan sinema olarak kabul edilmeyeceğini öngörmek zor değildir. Ancak teknoloji ile beraber gelen her dönüşüm, başlarda bir miktar dirençle karşılaşmıştır. Günümüzde yeni medya teknolojileri (örneğin Netflix ve benzerleri ya da televizyon kanallarının dijital platformları) nasıl televizyonu ve televizyon izleme deneyimini değiştiriyorsa, sinemayı da dönüştürebileceğini söylemek çok da iddialı bir varsayım değildir. Yakın gelecekte, bugün sinema olarak bildiğimiz şeyin başka bir şeye dönüşmesi olasıllğı çok da şaşırtıcı olmayacaktır. Neticede, bugün var olan tüm medya deneyimleri ve teknolojileri, gelecek teknolojiler ve deneyimler yolunda atılmıs bir adımdır.

Teknolojinin sanatı ve iletişimi dönüştürmesi, tarihsel olarak da pek çok farklı alanda görülür. Örneğin, fotoğraf makinesinin icadı, resim sanatını etkilemiş ve resimde perspektif kaygısını ortadan kaldırarak; İzlenimcilik, Kübizm gibi akımların doğmasına yol açmışır (Berger, 1986, s. 16-19). Yine Kubizm'in, dönemin bilimsel gelişmelerine paralel olarak ortaya çıkan yeni bir görme biçimi olduğu söylenebilir (Antmen, 2009, s. 46). Bu açıdan bakarsak, teknolojinin resim sanatını dönüştürdüğünü söylemek yanlış olmayacaktır. Peki, bir Rönesans ressamına Kübist bir resim gösterme şansımız olsaydı, Rönesans ressamı o eseri bir resim olarak kabul eder miydi? Böyle bir düşünce deneyi, teknolojinin etkilerinin ne kadar dönüştürücü olabileceğine dair oldukça iyi bir örnektir.

Teknolojinin belirleyiciliği, iletişim alanındaki en önemli kuramcılardan Marshall McLuhan'ın çalışmalarının da ana eksenini oluşturur. McLuhan "araç mesajdır" diyerek, dönemin teknolojisi ile şekillenen aracın birincilliğine ve insan ile toplum üzerindeki etkisine vurgu yapmıştır (McLuhan, 1964, s. 7-8). Eğer ki araç, McLuhan'ın öne sürdüğü gibi içerikten önce geliyorsa, iletişim ve sanat için dönüştürücü olması kaçınılmazdır.

Öte yandan, sinemanın geleceğine yönelik böyle bir öngörü yaparken konuşulması gereken bir diğer konu, kodlayıcı ve kodlayıcının bu yeni sinema türündeki rolüdür. Bir başka deyişle yapay zekanın yaratıcısının, izleyici ve eser ilisskisi içerisinde hangi konumda olduğudur. Burada sorulacak sorulardan biri, kodlayıcının bir tür yazar olarak kabul edilip edilemeyeceğidir. Bir diğer soru ise, yapay zekanın yaratıcısının hikaye anlatımı üzerinde bir otoritesi olup olmadığı ve varsa bunun nasıl bir otorite olduğudur. Örneğin, yapay zeka, kodlayıcısının yaratıcılı̆̆ının bir uzantısı ise, kodlayıcının otorite ya da yasa koyucu konumunda olmayan - post-modern - bir yazar olarak kabul edilebileceği söylenebilir. Öte yandan, eğer yapay zekanın yaratıcı özerkliğe sahip olduğunu kabul edersek, o zaman kodlayıcısından bağımsız olduğunu da iddia edebiliriz. Peki bu durumda kodlayıcı halen bir tür yazar statüsünde bulunabilir mi? Buradaki temel sorun, belki de yapay zekayı bir özne olarak kabul edip etmeyeceğimizdir. Böyle bir tartışma, mevcut makalenin sınırlarını aşsa da, dönüşümsel yaratıcılık ve / veya yaratıcı özerklik gösteren bir yapay zekanın özne olduğu söylenebilirse, o zaman kodlayıcının değil de yapay zekanın kendisinin bir tür - yine post-modern - yazar olduğu da iddia edilebilir.

Bu koşullarda ortaya çıkacak böyle bir sinema türü için aşılması gereken bir diğer zorluk ise, yapay zeka tarafindan üretilen senaryonun anlı görselleştirme yapabilmesidir. Günümüzde var olan teknolojilerin, yakın gelecekte böyle bir durumun mümkün olacağının işaretini verdiği söylenebilir. Bugün, sahneler gerçek oyuncular ve dekorla çekilmeden önce, sahnenin nasıl olacağını önceden görmek için kullanılan görselleştirme programları mevcuttur. Örneğin "Scene Maker" gibi bu gelişmiş programlar, verilen senaryoyu; karakterlerin duyguları ve kişilikleri gibi özelliklerini; hikayenin drama, komedi ya da aksiyon gibi türlerden hangisine ait olduğunu; ayrıca müzik ve 1şık gibi sinematografik öğeleri de yansıtacak şekilde, gerçeğe oldukça yakın ve 3 boyutlu bir biçimde görselleştirmeyi başarmıştır (Hanser, Mc Kevitt, Lunney, Condell, \& Ma, 2010). Söz konusu teknolojinin, yakın gelecekte izleyiciye gerçeği oldukça başarılı bir şekilde taklit edebilen sahneler ile bir deneyim sunmasını beklemek, çok da iddialı olmayacaktır.

\section{Tartı̧̧ma ve Sonuç}

Post-modern dönem, yeni iletişim teknolojilerinin hızlı bir gelişimine sahne olurken, interaktif dramaların da yine bu dönemde ve söz konusu teknolojiler vasıtasıyla gelişme göstermiş olması oldukça doğaldır. Bu açıdan, interaktif drama örneklerinin son dönemde yükselişe geçmesi, bir tesadüf olarak okunmamalıdır. Şüphesiz ki izleyicinin aktif olarak hikayenin gidişatına etki edebildiği bir anlatı türü, postmodernizmin yazarın otoritesini sarsmasına denk düşer. Dolayısıyla interaktif dramanın, yazarın iktidarını ortadan kaldırdığı ölçüde post-modern olduğu söylenebilir.

Öte yandan interaktif drama, Eco'nun yukarıda tartısılan açık yapıt kavramıyla da beraber düşünülebilir. İzleyicinin rolü, aynı açık yapıt kavramında olduğu gibi bir eş-yaratıcıllğga tekabül eder ve yine Eco'nun söylediği gibi bu durum bir oyuna benzer. Nasıl bir açık yapıtın sonsuz sayıda okuması 
mümkünse, interaktif dramanın da pek çok patikası vardır ve özellikle bir yapay zeka tarafından yazılırsa, söz konusu patikalar sonsuz sayıya ulaşabilir.

Bu noktada Barthes'ın görüşlerini hatırlayacak olursak, izleyici için esas olan eserden aldığı hazdır. Öyleyse izleyici, bir üst otorite (modern yazar) tarafindan belirli kurallara uygun ve doğrusal bir akışa sahip bir dramaya ihtiyaç duymaz. Eğer ki ana amaç eserden keyif almaksa, izleyicinin kendi anlatısını oluşturması veya anlatıya aktif bir şekilde katıllp olay örgüsü üzerinde karar verici yetkiye sahip olması, deneyimi olumlu anlamda etkileyebilir. Nasil ki post-modernistler, metnin anlamı konusunda herhangi bir otorite tanımıyor ve hiçbir okumayı daha doğru olarak kabul etmiyorsa, interaktif dramalarda da bir doğru ya da daha iyi patikanın olduğu varsayılmayacaktır. Her izleyicinin seçtiği yol, kendi hazzı doğrultusunda olacaktır ve hepsi birbirine eşit kabul edilecektir.

Yazarın yok olması, ilk başta çağımız için hikaye anlatımında radikal bir değişiklik olarak görünse de, yukarıda tartışıldığı gibi aslen, özellikle edebi metinlerde yazar ve iktidarı tarihsel süreçte göreceli olarak yeni unsurlardır. Hikaye anlatımının kolektif ve değişken yapısını dönüştüren yazı, alfabe, matbaa ve modernitenin, post-modernizme yenilmesi ve yazar ile sabit anlatıları ortadan kaldırması çok da şaşırtıcı olmayacaktır. Bu anlamda yapay zekanın bildiğimiz anlamda bir yazarı olmayan senaryolar üretmesi, postmodernitede yazarın ölümüne denk düşer.

Öte yandan, böyle bir deneyimin hala sinema sanatı olarak değerlendirilip değerlendirilmeyeceği de tartışlabilir. Yapay zeka ile beraber tercihler yapan ve yeni patikalar üreten izleyici, bir film mi izler yoksa bir oyun mu oynar? Yaşanan deneyim, şüphesiz, bugün film izleme deneyimi olarak adlandırdığımızla aynı değildir. Benzer şekilde, ortaya çıkan ürün de günümüzde sinema sanatı olarak kabul edilen eserlerden farklıdır. Peki bu durum, bu yeni deneyimin sinema olamayacağını söylemek için yeterli midir? Yeni teknolojiler ve bu teknolojilerin toplumsal hayata etkileri, ihtiyaç duydukları yeni görme biçimleriyle beraber her zaman sanat ve iletişim alanında dönüştürücü olmuştur ve çoğunluklu bu dönüşümler kaçınılmazdır. Elbette sıklıkla dirençle karşılaşırlar, fakat söz konusu direnişler teknolojinin gücü karşısında genellikle yetersiz kalır. Dolayısıyla bugün reddedilen ve alanın dışına itilen yeni ürünler, yarının yükselen akımlarının öncü eserleri olabilir. Bir başka deyişle, bir gün sinema sanatından anladığımız şey, bugünkü ile aynı olmayabilir. Bu dönüşümün nasıl evrileceği kesin bir şekilde söylenemeyecek olsa da, bir dönüşümün gerçekleşmesi kaçınılmazdır.

Yapay zeka tarafindan üretilen senaryoların önündeki en büyük zorluğun, yapay zekanın yaratıcıllğı olduğu söylenebilir. Ancak günümüzde yapay zekanın geldiği nokta düşünüldüğünde, yakın gelecekte yaratıcılık açısından yaşanacak büyük gelişmeler şaşırtıcı olmayacaktır. Yaratıcılığın insana mahsus bir özellik olarak kabul görmesi aslında hala Descartes'ın düalistik düşüncesinin bir uzantısıdır. Descartes (1641/2008) bedenlerimizin bir mekanizma olduğunu, fakat onu yönlendiren gücün bedenin içindeki ruh olduğunu iddia etmişti. Modern felsefenin bu bilindik fikrini bugün yaratıcılık tartışmasının içinde de görebiliriz. Bir yapay zekanın insan aklının yaptığı gibi tasarımlar ortaya koyamayacağını söylemek, aynı zamanda insanın yaratabilme yeteneğinin bu düalistik bakış açısı nedeniyle benimsenmiş bir inanışı olabilir. Ancak güncel bilimsel çalışmalar, ruh ve beden düalizmi bir yana, yaratıcılı̆̆ımızın kaynağı beynimizi, aslında oldukça kompleks bir mekanizma gibi çalışan bir organ düzeyinde ele almaktadır. Bu açıdan bakıldığında yaratıcılık bağlamında, insan zekası ile yapay zeka arasındaki farkın kapanmasına yönelik tartışma artarak devam edecek gibi gözükmektedir. Dolayısıyla yaratıcıllğın, insan zekası ve yapay zeka arasındaki muğlaklaşmaya başlayan sınırda nerede durduğu önemli bir soru haline gelmektedir.

İnteraktif dramalar, bugün çok önemli olmayan yeni bir yönelim gibi görünse de sinemanın ve senaristin geleceğine dair şimdiden önemli ipuçları barındırır. Elbette burada tartışılan öngörü ve tartışma doğrusal anlatıların ya da insan yazımı senaryoların ortadan kalkacağı şeklinde yorumlanmamalıdır. Ancak, teknoloji ile ortaya çıkan yeni görme biçimleri, yeni tüketim alışkanlıkları, yeni bakış açıları ve sanatın dönüşümü, sinema açısından da bugün var olan eserlerden çok farklı üretimler ortaya çıkmasına ve izleyiciler açısından yeni deneyimler yaratılmasına neden olabilir. Söz konusu yeni deneyimlerin sanat olarak kabul edilip edilemeyeceği ya da ana akım tüketim alışkanlığı haline gelip gelemeyeceği gibi tartışılması gereken yeni soruların sorulması ise çok uzak olmayan bir gelecekte ihtimal dahilinde gözükmektedir.

Bu çalışmanın sınırlılıkları; interaktif dramada izleyici deneyimi ve yapay zekanın yaratıcıllğı üzerine olan değerlendirmeleri, mevcut literatür ve kuramsal tartışmalar ve bu tartışmaların işaret ettiği noktalar üzerinden değerlendirmektir. Gerek senarist gerekse de yapay zeka tarafindan yazılmış senaryolarla interaktif dramanın izleyiciler üzerindeki deneyimini ölçen çalışmalar, özellikle izleyici üzerinde interaktif 
drama deneyimi ile geleneksel drama deneyimini karşılaştıran nitel çalışmalar alana katkı sağlayacak öneriler olarak değerlendirilebilir.

\section{Etik Beyan}

"Post-modern Dönemde Senaristin ve İ̃leyicinin Rolü: Yapay Zeka, Interaktif Drama ve Sinemann Geleceğine Dair Bir Öngörï” başlıklı çalışmanın yazım sürecinde bilimsel kurallara, etik ve alıntı kurallarına uyulmuş; toplanan veriler üzerinde herhangi bir tahrifat yapılmamış ve bu çalışma herhangi başka bir akademik yayın ortamına değerlendirme için gönderilmemiştir.

\section{Kaynakça}

Antmen, A. (2009). 20. yüzynl batı sanatında akımlar (2. b.). İstanbul: Sel.

Aristoteles. (2017). Poetika: șïr sanatı üstüne. (S. Rifat, Çev.) İstanbul: Can.

Barthes, R. (1975). The pleasure of the text. (R. Miller, Çev.) New York: Hill and Wang.

Barthes, R. (1977). The death of the author: Image, music, text. London: Fontana.

Baudry, J. L. (1974). Ideological effects of the basic cinematographic apparatus. Film Quarterly, 28(2), 39-47.

Bauman, Z. (2018). Yasa koyucular ile yorumcular (5. basım). (K. Atakay, Çev.) İstanbul: Metis.

Berger, J. (1986). Görme biçimleri. (Y. Salman, Çev.) İstanbul: Metis.

Boden, M. A. (1998). Creativity and artificial intelligence. Artificial Intelligence, 103(1-2), 347-356. doi:10.1016/S00043702(98)00055-1

Boden, M. A. (2009). Computer models of creativity. AI Magazine, 30(3) 23-34. doi:10.1609/aimag.v30i3.2254

Bostan, B. ve Marsh, T. (2012). Fundemantals of interactive storytelling. Online Academic Journal of Information Technology, 3(8), 19-42.

Campbell, J. (2013). Kahramanın sonsuzyolculuğu. (S. Gürses, Çev.) İstanbul: Kabalc1.

Crawford, C. (2013). On interactive storytelling. San Francisco: New Riders.

Descartes, R. (2008). Meditations on first philosophy. (M. Moriarty, Çev.) Oxford: Oxford University.

Eco, U. (1983). Postscript to the name of the rose. Orlando: Harcourt, Brace, Jovanovich.

Eco, U. (1992). Açık yapıt. (P. Savaş, Çev.) İstanbul: Can.

Eco, U. (2008). Yorum ve aşır yorum. (K. Atakay, Cev.) İstanbul: Can.

Fossa, F. (2017). Creativity and the machine. How technology reshapes language. Ordarek Studies in Philosopy of Literature, Aesthetics, and New Media, 2(3), 299-314.

Foucault, M. (1998). What is an author. D. Preziosi (Dü.) içinde, The art of art history: A critical anthology (s. 299-314). Oxford: Oxford University Press.

Friedman, A. K. (Prodüktör) ve Sharp, O. (Yöneten). (2017). It's No Game [Sinema Filmi]. ABD.

Gervás, P. (2009). Computational approaches to storytelling and creativity. AI Magazine, 30(3), 49. doi:10.1609/aimag.v30i3.2250

Hales, C. (2005). Cinematic interaction: From kinoautomat to cause and effect. Digital Creativity, 16(1), 54. doi:54-64. DOI: $10.1080 / 14626260500147777$

Hanser, E., Mc Kevitt, P., Lunney, T., Condell, J. ve Ma, M. (2010). SceneMaker: Multimodal visualisation of natural language film scripts. International Conference on Knowledge-Based and Intelligent Information and Engineering Systems. Berlin: Springer.

Jennings, E. K. (2010). Developing creativity: Artificial barriers in artificial intelligence. Minds and Machines, 20(4), 489-501. doi:10.1007/s11023-010-9206-y

Jensen, J. F. (1998). 'Interactivity': Tracing a new concept in media and communication studies. Nordicom Review, 19(2), 185-204.

K., P. B. (Prodüktör) ve T., W. (Yöneten). (2016). Late Shift [Sinema Filmi]. İsviçre.

Kalas, L. (Prodüktör), \& Činčera, R. R. (Yöneten). (1967). Kinoautomat: One Man and His House [Sinema Filmi]. Çekoslavakya.

Kenway, J. (1995). Having a postmodernist turn or postmodernist angst: A disorder experienced by an author who is not yet dead or even close to it. R. Smith, \& P. Wexler (Ed.), içinde, After Post-modernism: Education, Politics and Identity (s. 36-55). London: The Falmer.

Kiousis, S. (2002). Interactivity: a concept explication. New Media \& Society, 4(3), 355-383. doi:10.1177/146144480200400303

Kortschak, A. K. (Prodüktör), \& Sharp, O. (Yöneten). (2016). Sunspring [Sinema Filmi]. ABD.

Kundera, M. (2007). Varolmanın dayanılmaz hafifliği. (F. Özgüven, Çev.) İstanbul: İletişim.

Laurel, B. K. (1986). Toward the design of a computer based interactive fantasy system. Ohio: Ohio State University.

Lebowitz, M. (1985). Story-telling as planning. Poetics, 14(6), 483-502.

Logan, R. K. (2014). Yazı ve alfabe etkisi. P. H. Crowley (Ed.) içinde, İletişim Taribi: Teknoloji, Kültür, Toplum (B. Ersöz, Çev.), (99-106). Ankara: Siyasal.

Mateas, M. (2002). Interactive drama, art and artificial intelligence. Pittsburgh: Carnegie Mellon University School of Computer Science Computer Science Department.

Matteas, M. ve Stern, A. (2006). Façade: An experiment in building a fully-realized interactive drama. Game Developers Conference, (s. 4-8). 
McLean, R. (Prodüktör), ve Slade, D. (Yöneten). (2018). Black Mirror: Bandersnatch [Sinema Filmi]. ABD: Netflix.

McLuhan, M. (1964). The medium is the message. Understanding Media: The Extensions of Man içinde (7-21). New York: McGraw Hill.

Meehan, J. R. (1977). Tale-Spin an interactive program that writes stories. In Proceedings of the 5th International Joint Conference on Artificial Inteligence, (s. 91).

Peters, M. W. (1998). Towards artificial forms of intelligence, creativity, and surprise. M. A. Gernsbacher ve S. J. Derry (Ed.), Proceedings of the Twentieth Annual Conference of the Cognitive Science Society içinde (s. 836-841). Madison: University of Wisconsin.

Rafaeli, S. (1988). From new media to communication. (R. Hawkins, J. M. Wiemann ve S. Pingree, Ed.) Sage Annual Review of Communication Research: Advancing Communication Science: Merging Mass and Interpersonal Processes, 110-134.

Rafaeli, S. ve Ariel, Y. (2007). Assessing interactivity in computer-mediated research. K. Y. A. N. Joinson (Ed.) içinde, The Oxford handbook of Internet psychology (s. 71-89). Oxford, UK: Oxford University Press.

Rigel, N. (2010). Umberto Eco ile metin okuma. N. Rigel, Ş. Çağlar ve A. Cengiz (Ed.) içinde, Eco dersleri: Yankılanan metinler nasil okunur (s. 19-33). İstanbul: Anonim.

Rogers, E. M. (1986). Communication technology: The new media in new media. New York: Free Press.

Rosenau, P. M. (2004). Post-moderniżm ve toplum bilimleri. (T. Birkan, Çev.) Ankara: Bilim ve Sanat.

Smith, A. (1980). Goodbye Guthenberg: the newspaper revolution of 1980's. Oxford: Oxford University Press.

Steuer, J. (1992). Defining virtual reality: Dimensions determining telepresence. Journal of Communication, 42(4), 79-93. doi:10.1111/j.1460-2466.1992.tb00812.x

Szilas, N. (1999). Interactive Drama on Computer: Beyond Linear Narrative. In AAAI Fall symposium on narrative intelligence, 144, s. 150-156.

This is what happens when an AI-written screenplay is made into a film. (Haziran 10 2016). The Guardian. Mart 2019 tarihinde https://www.theguardian.com/technology/2016/jun/10/artificial-intelligence-screenplay-sunspringsilicon-valley-thomas-middleditch-ai adresinden alınd1.

Williams, F., Rice, E. R., \& Rogers, E. (1988). Research methods and the new media. New York: Free Press.

\section{EXTENDED ABSTRACT}

The purpose of this paper is to discuss audience experience in interactive dramas, and if it will be possible in the future to have this experience via scenarios written by artificial intelligence, within the scope of writer's diminishing authority and reader's / audience's active role in the post-modern era. For this purpose; first, the discussions on post-modern era, death of the author and birth of the reader was cited. This discussion stated that in the modern era, authors had an authority over the meaning of texts. If one wanted to understand the meaning of a specific text, then they had to understand the intentions of the author, thus seek clues in author's life, thoughts etc. This meant that the text only had one true meaning, and the role of the reader was to find it. However, that relationship between the author and the reader had changed in the post-modern era, and the reader undertook a more active role on the interpretation of text. The author was no longer regarded as the single authority over the meaning of the text, and the reader's interpretations were started to be regarded as equally valid. In other words, a specific text did not have one single meaning; it could be interpreted in different ways. This meant the death of the author, and the birth of the reader.

After this discussion, the concept of interactivity, interactive dramas, role of the audience and audience experience in comparison with linear storytelling were addressed. Interactive drama refers to a narrative genre that allows the audience (or participant) to directly intervene the story flow. Thus, in an interactive drama, the audience makes choices that change the direction of the narrative. There are different pathways for each choice, and these choices determine the evolution of the story. This means, in an interactive drama, the audience could be regarded as taking an active role. On the other hand, interactivity changes the audience experience when compared to linear drama. While it allows audience to take an active role, it also transforms the connection between the audience and the protagonists of the narrative. Linear drama gives audience a journey in which they travel and see how the characters are affected by the line of events. In interactive drama, however, curiosity element somewhat changes, as audience is now focused on what to choose.

This discussion was followed by the literature on artificial intelligence and creativity. Within the scope of these literature and discussions, it was questioned that whether artificial intelligence can reach human creativity. If an artificial intelligence provides standard and predictable storylines due to its coding, it cannot be regarded as creative. Thus, the question is, whether artificial intelligence can produce unexpected, nonstandard stories with the element of surprise. On the other hand, another discussion asks that, does the narrative created by artificial intelligence belong to the coder or mastermind behind it? So 
the discussion leads us to the concept of creative autonomy. If an artificial intelligence can surpass the intentions of its creator and change the standards, then we might say it has creative autonomy.

If it is possible for an artificial intelligence to achieve that, it might open new ways for cinema and audience experience. For instance, audience might have an interactive cinema experience via scenarios produced by artificial intelligence. However, it will only be possible to have this experience in near future by means of a technology which can create instant scenarios and pathways - according to genre, character etc. choices of the audience - and instantly visualize them. This will make the audience co-creator of the narrative, where there is no higher authority then themselves. Thus, it will also mean the death of the scriptwriter as we know it. But even if that happens, the question still stands: Can the outcome of such production still be considered as cinema?

In conclusion, the biggest obstacle standing in the way of such an experience is the creative autonomy of an artificial intelligence. Of course, even if that happens, that will not be the end of scriptwriters or the linear narratives. However, for the fact that it will give the audience an active role and diminish the higher authority of the author, this genre will have strong relationship with the post-modern view of author / audience roles and relationship. In addition, it might produce new ways of seeing, new consumption habits, new experiences, and new ways of creating. But can such productions still be regarded as art, or do they have the potential of become a mainstream consumption habit? These are important questions, however out of the scope of this article. 